\title{
Challenging modernity: The Luntas, modern ludruk and young audiences' acceptance
}

\author{
Firtha Ayu Rachmasari ${ }^{1^{*}}$, Delmarrich Bilga Ayu Permatasari ${ }^{2}$ \\ ${ }^{1}$ Universitas Airlangga, Indonesia \\ ${ }^{2}$ Universitas Bhayangkara, Indonesia \\ ${ }^{*}$ Corresponding author \\ E-mail address: firtharashi@gmail.com \\ DOI: https://doi.org/10.21107/sml.v3i2.7879
}

\begin{tabular}{|c|c|}
\hline Article Info & Abstract \\
\hline $\begin{array}{l}\text { Keywords: } \\
\text { Modern ludruk } \\
\text { Reception } \\
\text { Stuart Hall } \\
\text { Urban community } \\
\text { Youth subculture }\end{array}$ & $\begin{array}{l}\text { The Luntas, a modern ludruk group from Surabaya, is bringing back ludruk } \\
\text { with a new style. This is an effort and strategy to attract urban communities, } \\
\text { especially young people. This study aims to determine whether the } \\
\text { strategies and efforts of The Luntas are successful. The researcher explores } \\
\text { the audience's acceptance by using Stuart Hall's theory of how the message } \\
\text { is conveyed (encoding) and the attitude of receiving the message (decoding). } \\
\text { The data was collected through in-depth interviews with the founders of } \\
\text { The Luntas as the encoder and the audience as the decoder. The process of } \\
\text { selecting audiences as informants must meet several criteria: the informant is } \\
\text { the audience for the show "Arti Sebuah JAS" performance; age between } 15 \text { to } \\
30 \text { years old; has watched The Luntas live performance more aged between } \\
15 \text { and } 30 \text { years; have watched The Luntas live performance more than once; } \\
\text { have watched other ludruk shows besides The Luntas at least once. Based } \\
\text { on these criteria, the researcher found nine informants. The study results } \\
\text { found that five informants in accordance with the dominant-hegemonic } \\
\text { category agreed with and accepted The Luntas strategy. Meanwhile, four } \\
\text { other informants understood the strategy but tended to negotiate. }\end{array}$ \\
\hline
\end{tabular}

Citation suggestion:

Rachmasari, F. A., \& Permatasari, D. B. A. (2020). Challenging modernity: The Luntas, modern ludruk and young audiences' acceptance. Simulacra, 3(2), 139-152. https://doi.org/10.21107/sml.v3i2.7879

Received 14 July 2020; Received in revised form 30 September 2020; Accepted 6 October 2020; Published online 25 November 2020. 


\section{Introduction}

Ludruk is one of the traditional arts and regional cultures originating from East Java. More specifically, ludruk is a traditional folk performance drama with a story that is closely related to everyday life through its symbolic signs. Recently, ludruk has been abandoned and is considered less attractive to urban communities, especially young people. As a social activity and performing art (Azali, 2016; Peacock, 2005), East Javanese art products seem to be experiencing a setback. This can be seen from the ludruk performances, which are increasingly rare in East Java. This is also emphasized by Setyawati (2019), who stated that ludruk is a regional art that experiences ups and downs in maintaining its existence. Based on this phenomenon, a group of Surabaya youths is determined to keep ludruk alive and help ludruk to conquer the modern era so that ludruk is not neglected and lost. This group of young people formed a ludruk group called The Luntas (Ludrukan Nomnoman Tjap Soeroboio or Ludruk Pemuda a la Soeroboio).

The Luntas was founded on 21 January 2015 by Robets Bayoned and three other co-founders, namely Aixa Paramita, Ipul Bayoned, and Devi Istyanita. The background of the establishment of The Luntas was the concern about the future of ludruk in East Java, especially Surabaya. Robets wanted to eliminate the stigma attached to young people who think ludruk is an outdated work of art. He also wanted to raise awareness about ludruk among young people. Therefore, The Luntas was established to bring back the art of ludruk with a newer style that attracts young people without losing the essential elements of ludruk. In every show, The Luntas does not only present important aspects of ludruk. They also combine it with more attractive aspects to young people, such as appearance, costumes, backdrops, and story titles. The Luntas modified each of these elements. In several performances, The Luntas presents ancient ludruk stories such as "Sarip Tambak Oso" ("Sarip from Tambak Oso") and "Babad Alas Suroboyo." However, The Luntas replaced the old story titles with new titles and small details that aroused people's curiosity. Some of their innovative titles are "Sarip Reborn" and "Legend of Joko Dolog." The Luntas also made new stories, such as "Suster Gepeng," taken from the Surabaya urban legend about the ghost of a nurse who died in an accident whose body was crushed flat. 'Gepeng' means 'flat' in Indonesian.

The modern elements in The Luntas' performance have a positive impact. As Ismail (2017) stated, the emergence of the modernization process has brought many changes in the context of entertainment. Most of the audience who watched The Luntas show were young people. The positive response of young people to The Luntas can be seen in the show, which took place on 21 September 2018 at the SwissBelinn Manyar Hotel, Surabaya. In its performance, The Luntas presents a story entitled "Arti Sebuah JAS" or "The Meaning of a JAS" in commemoration of World Peace Day. There are about 60 to 70 spectators in this performance. The seats provided were almost full of people who were enthusiastic about the show. Most of the audience who attended were young people, such as high school students, college students, and young workers. During the show, both young and old audiences laughed out loud. This indicates that they enjoyed the show and looked quite amused by Robets Bayoned and friends' performance. 
Based on this phenomenon, the researchers are interested in exploring and understanding: first, the efforts and strategies that have been made by The Luntas so that urban communities, especially young people, are increasingly interested in watching ludruk performances; and second, the acceptance of the city community who enjoys modern ludruk brought by The Luntas. This research was conducted to determine the facts behind The Luntas' efforts in preserving the ludruk culture in Surabaya. This can be a sign of social change in the urban community of Surabaya as well as knowing the Surabaya people's lifestyle in preserving ludruk as a product of Indonesian art.

There has been much research on ludruk art. However, only a few specifically focus on the object of The Luntas as an art worker. Among the studies that used The Luntas as an object was Ilham Bimantara Putra entitled The Art of Ludruk in Surabaya (Descriptive Study Regarding the Efforts of the "Luntas" in Reviving the Existence of Ludruk Traditional Art as a Tourist Attraction in Surabaya). In his research, Putra (2018) studied the preservation and existence of ludruk art in Surabaya from Surabaya tourism. From the results of this study, it can be seen that The Luntas provides a forum for the community, especially young people, to learn the art of ludruk in order to maintain its existence. Putra's research is certainly different from the current research because this study aims to determine the sustainability and existence of The Luntas and determine audience acceptance of The Luntas show.

\section{Method}

This study used qualitative research methods to explore the unquantified phenomenon and tended to be descriptive
(Ghony \& Almanshur, 2014). Descriptive research described and illustrated an existing phenomenon, both natural and humanmade, and focused on the characteristics, quality, and linkages between the activities (Sukmadinata, 2011). According to Nawawi \& Martini (1996), descriptive research described or depicted the research object based on the facts that appear and as it is.

This study used two kinds of informants. The first was the founders of The Luntas, and the second was the audiences for The Luntas' performance. The researcher chose the founders of The Luntas as one of the informants because the researcher wanted to find out what strategies were used to attract audiences, especially young audiences. Because in reception research, before we examine the decoder (audience), the researcher must first look at the encoding process carried out by the encoder, in this case, The Luntas.

As discussed earlier, this study aimed to understand the reception of The Luntas' audience to the modern ludruk; therefore, the primary informants in this study were audiences of The Luntas. The method that was used to select and determine research informants was a purposive sampling method. The purposive sampling method was used to select subjects who knew about the phenomenon studied (Iskandar, 2009). The informants of the research were selected by matching them with some of the researcher's criteria. Those criteria were: (1) the informant who was the audience of The Luntas' performance entitled "Arti Sebuah JAS"; (2) the informant's ages must be between 15 to 30 years old; (3) the informant had already watched The Luntas live performance more than once; (4) the informant also watched other ludruk performances besides The Luntas at least once. 
The performance by The Luntas to commemorate World Peace Day was the main reason to choose "Arti Sebuah JAS" as the object of research. The audience who came to watch the performance must reserve the ticket, which means they were interested in ludruk performance. This performance is slightlydifferentfromtheregularperformance of The Luntas held in a traditional coffee shop. On those performances, the audience had a diverse motive to come to the coffee shop. Furthermore, in the second criteria, the researcher focused on young audiences as informants because young people were one of the most prominent target markets that The Luntas wanted to reach. The age range of informants on the second criteria was formed based on the Youth Law of the Republic of Indonesia number 40, 2009, which emphasized that Indonesian youth's age limit is between 15 to 30 years old (Prabowo, 2013). The third and fourth criteria were formed to get real data from experienced informants. According to Storey (2006), in the reception process, the audiences retranslate the phenomenon's message by referring to their experience, history, and other factors. The informants who watched The Luntas' performance and other ludruk performances experienced the real situation and atmosphere of the performances to describe their experience and feeling in more detail.

Furthermore, to get the informant who meets the criteria, the researcher distributed a questionnaire that was filled out during registration. The questionnaire contained questions related to audience information such as name, age, how many times they had watched The Luntas' performance, and so on. Through this information, the researcher could select the informant. The researcher found nine informants from the selection process: (1) Dhimas was an 18-year-old high school student who had watched The Luntas' performance three times; (2) Aziz was 24 years old graduate student. Besides The Luntas, Aziz watched other ludruk performances, such as Putra Buana and Ludruk Margono; (3) Rany was a 25-year-old book editor. Besides watching The Luntas live performance, Rany also experienced watching the performance of Surobudoyo; (4) Isna was a 20-year-old undergraduate student. Isna believes that watching ludruk was entertainment that gained knowledge over the culture; (5) Alya was 18 years old, an undergraduate student. Alya had watched other ludruk groups. Alya said that other ludruk groups' performances are different from The Luntas performance; (6) Danang was an 18-year-old freelance. Besides The Luntas' performance, he had watched other conventional ludruk performances such as the Supali CS group; (7) Hamdan was 22 years old, an undergraduate student. Besides The Luntas, Hamdan had watched other ludruk groups from Sumenep Madura; and (8) Adnan was a 25-year-old graduate student. During his college years, Adnan joined a gamelan group on campus. Therefore, he watched ludruk to look for gamelan references because there were gamelan players on ludruk performance. Besides The Luntas performance, Adnan had watched Irama Budaya ludruk performance and some other ludruk performances from Mojokerto and Jombang; (9) Dewi was a 23-year-old graduate student. Besides The Luntas, Dewi also watched ludruk from the Kirun CS group and the Maduran ludruk group.

The researcher used in-depth interviews to collect data for this study. An in-depth interview was a process of obtaining information for research purposes by arranging dialogue between researcher and 
informant or subject related to the research (Iskandar, 2009). In order to get the needed information, the interview methods that had been used were a structured interview and an unstructured interview. The interview process itself was held on 22-23 September 2018. The interview was not conducted on the same day and place due to time limitations and many informants who had to leave the place after the performance was finished because the performance finished late at night. However, before conducting interviews with the audiences, the researcher had conducted interviews with the founders of The Luntas, namely Robets Bayoned and Aixa Paramita, on 21 September 2018 when The Luntas had their performance entitled "Arti Sebuah JAS." The interview with the founders of The Luntas aimed to dig up the efforts and strategies carried by The Luntas to attract the audiences, especially youth.

The next step was the data analysis method. Thedata analysis method categorizes data sequences, organizing them into a basic pattern, category, and description unit (Iskandar, 2009). Data analysis was intended to organize the collected data consisting of field notes, researcher comments, pictures, images, documents, reports, etc. The data analysis method used in this study was the reception analysis method, which was the theory of message acceptance based on an understanding of encoding and decoding or how it was conveyed and the attitude of acceptance of the message. The researcher tried to examine audience acceptance of the consumed text by using a reception analysis method. The stages of data analysis in this study were: (a) the first stage was examining the results of the interview in the form of transcripts, which were then categorized into different categories, such as questions, statements, comments, and so on; (b) the second stage was analyzing the data that had been obtained.

The researcher used Stuart Hall's encoding decoding method to analyze the data. Encoding was the process of creating messages according to specific codes and encoding; in this case, it could be in the form of a story that was packed in a performance, how to pack the performance, and the messages inserted into each performance. Meanwhile, decoding was the process of using code to interpret messages. Decoding was in the form of interview data with The Luntas' audiences after they had seen the performance presented by The Luntas; (c) the third step was obtaining the data from the two previous steps and then approaching the final step that was the in-depth analysis of the data to extract the conclusions.

\section{Results and Discussion}

\section{The Luntas' efforts and strategies in attracting youth}

The main reason for the establishment of The Luntas is to revive the spirit of ludruk in modern society, especially for young people. The founders of Luntas, Robets, and Mita share stories of the efforts and strategies that have been made to achieve their goals. One of The Luntas' strategies to attract audiences, especially young people, to watch its ludruk performances is language use. The language used in The Luntas performance is the everyday language of the people of Surabaya. Mita considered that ludruk' older generation' uses language that is too formal or even figurative language. Formal language and figurative language may be considered too difficult for most young people to understand. The formal style in Javanese speech (krama) is closely related to politeness or an expression of a speaker's concern 
for other people/interlocutors (Suryadi, 2018). This fact causes the performance of The Luntas to use everyday language that is easier for the audience to understand. Another strategy of The Luntas is to follow the audience's sense of humour. The Luntas uses understandable jokes, such as slapstick humor, that can be accepted and enjoyed by all society elements.

Robets added that in addition to language and humor, TheLuntas' performancewas also supported by performance modifications that attracted the audience. Ludruk requires many instruments that must be prepared to make a complete performance. The Luntas preserves this tradition and adds a performance art form urgently needed in the process, namely Production Management of Pagelaran (performance) (Bisri, 2000). Traditional musical instruments such as the gamelan and its players, costumes, traditional dancers, stage, and other musical instruments are examples of essential elements of ludruk that require time and budget. Robets said that to trim these complicated elements, The Luntas had produced two modified plays, namely Ludruk Pagelaran or Ludruk Jangkep (complete ludruk) and Ludruk Ringkes (short ludruk). Ludruk Pagelaran is one type of ludruk show, almost the same as other conventional ludruk shows. The drama is performed by 15 to 20 players on stage, using exclusive properties and accompanied by gamelan players and their instruments.

Meanwhile, Ludruk Ringkes is a simplified version whose elements depend on the performance's location and cost. Ludruk Ringkes does not require many properties and players, only 3 to 5 people, because staging cannot happen in real-time. In terms of musical instruments, gamelan music groups are transformed into modern technology, such as recording gamelan songs from laptops and connecting to a sound system. The initial idea of Ludruk Ringkes was to make The Luntas able to do shows anywhere. The limited space sometimes makes traditional ludruk challenging to play. However, Ludruk Ringkes overcomes the problem. Ludruk Ringkes is more practical, so it minimizes problems that may occur and is more economical. With the Ludruk Ringkes method, The Luntas can play in almost all places such as hotels, campuses, and schools, even in traditional coffee shops that do not have large spaces.

According to Mita, The Luntas wants to enter any society element in which conventional ludruk cannot enter. She hopes that with this strategy, ludruk can be recognized and enjoyed by all modern society levels, especially young people, by making access to ludruk easier. Young people are the target of ludruk performances because, based on Bintari \& Darmawan (2016), youth play an essential role in continuing the nation's noble values as a foundation and moral strength well as agents of positive. Apart from that, according to Mita, today's urban people like everything practical. The urban lifestyle encourages people to move faster, matching urban life's motto: 'time is money.' That motto should be considered when making a play. The performance of The Luntas also did not take too long. Therefore, the audience, especially young people, would not be bored. The duration of the play is usually around two to three hours. This duration is considered shorter than the typical ludruk. The East Java ludruk play consists of a relatively long series of performances, including introductions, remo dance, gambyong dance, a series of jokes or comedies, main plays, and closing sequences (Prasisko, 2018). The show takes much time; it may start at night and continues until the next morning. 
Another strategy is to modify the storyline by including modern elements in each performance. Old Ludruk may not attract the audience's attention because it has the same storyline and is repeated. According to Robets, even though it includes modern elements, The Luntas tries to modify the storyline without making significant changes in the play. In its performance, The Luntas continues to perform Remo, Jula-Juli, and Bedayan dances. However, the performances are packaged in different styles, for example, changing the remo dance costumes to be simpler by using costumes a la The Luntas. The dance movements themselves are not changed, only the costumes. In addition, The Luntas carries the theme of a contemporary play or changes the story title intending to attract audience interest. For example, the story play "Ken Arok" was changed to a new title, "King Arok," or the story play of "Roro Jonggrang" is changed into "Thousand Temples." The Luntas also raised the urban legend of Surabaya in its stories, for example, "Sundel Bolong Jembatan Nginden ("Sundel Bolong Nginden Bridge"). The play, which raised the local urban legend, seems to favor the surrounding community because of the closeness of the story to their daily lives.

Roberts and Mita stated that the modern elements in The Luntas show had a good impact, especially for young audiences. Therefore, The Luntas can be one of the subcultural communities of youth in ludruk culture. Gramsci, Althusser, and Barthes argue that youth subcultures try to express their contradictions and resistance to dominant cultures. On the other hand, Hebdige said that young people's use of certain symbols is a form of resistance to the dominant system order. Hebdige added that the subculture developed by young people is a form of symbolic resistance to the dominant culture or the parents (Sugihartati, 2017). The term youth subculture is a type of subculture linked to young people's specific behaviour, their tendency towards particular value preferences, acceptance, or rejection of specific rules (Smolik, 2013). A subculture is a form of rejection or offer of new things from the culture itself. Through subculture, there are communities present that are formed on something in common, which is not being mainstreamed to create something new in terms of culture (Riswari, 2019). As Barker (2014) said that the youth subculture not only leads to those who commit crimes and delinquency but can also be shown as leisure activities.

The Luntas also realizes that the urban communities, especially in Surabaya, are technology literate. The fact that young people like new and innovative things, such as spending most of their time online, so the promotion and selection of media follow young people (Njo et al., 2017). Therefore, social media such as Instagram, Youtube, and WhatsApp are being used to promote The Luntas. The official Instagram account of The Luntas itself at @theluntas (see picture 1) has been followed by 1683 followers (as of 10 October 2018). In this account, The Luntas is sharing activities that they do, both inside and outside the performance. In addition, the account also shares information or uploads their performance posters so that their followers on Instagram can quickly get information about the time and the place of the next The Luntas' performance.

The Luntas also uploads their recorded performance into their Youtube channel. One of their uploaded videos entitled Ludruk Luntas "Suster Gepeng Part 2" has been watched 1545 times. This is intended to introduce The Luntas to the public. They hope that the public interest may increase 


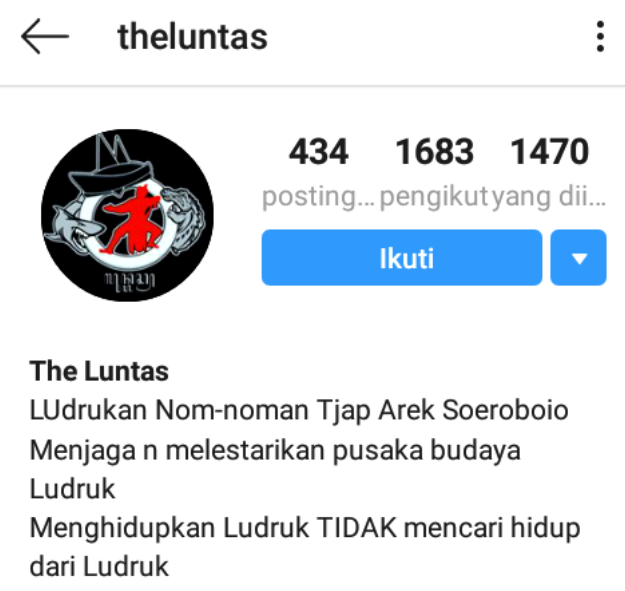

Picture 1. The Luntas Instagram account (https://www.instagram.com/theluntas/)

after watching their video and decide to attend The Luntas live performance. Youtube is used as promotion media by The Luntas because they think that many young people change their entertainment media from television to Youtube. Youtube has more than one billion users, almost one-third of all internet users, and every day people watch hundreds of millions of hours of video on Youtube and generate billions of views. As a whole, Youtube has reached more viewers aged 18-49 than any cable network in the world (Faiqah et al., 2016). The wide range of viewers on the internet might help them promote their work and, more importantly, the ludruk itself. The use of social media as the media of communication has been previously applied by another ludruk group which is called Marsuadi Laras. Social media opens a two-way communication model between the ludruk group and the prospective audiences of their performance. Social media aims to show to the public that today's ludruk performance is more attractive because they apply fresh and up-to-date concepts (Setyawati, 2019). The effort is made to attract the younger generation's attention and create curiosity through promotional footage on social media.

The Luntas also promotes their activities, such as their next performance to their fans or loyal audiences, through WhatsApp messages. In this era, any information can be spread faster through online messaging applications such as WhatsApp. Trisnani (2017) stated that WhatsApp is very effective because it is is more satisfactory, faster, and on target. By spreading the message on WhatsApp, they hope that The Luntas' next performance information will spread easily and quickly with chain messages. The Luntas, with their social media, have tried to maintain their art life as opinion Hendriani (2012) revealing that some ludruk artists take advantage of new media, the internet, as a way to offer ludruk and to complement what has become traditional media so far.

\section{Young audiences' reception towards the Luntas' modern ludruk}

The researcher analyzed interview data by using the reception analysis theory. Reception analysis is a study to dig up how audiences interpret and how audiences perceive text or phenomena (Dwita \& Sommaliagustina, 2018). The beginning concept of reception analysis theory is encoding/decoding. Stuart Hall's encoding/decoding model becomes a theoretical framework for empirical studies of reception (Ida, 2011). The encoding/decoding communication model proposed by Stuart Hall can be seen in picture number 2 .

The encoding process describes that the process of producing and forming meaningful messages carrying out by the message maker/encoder is free to be interpreted by the audience/decoder. The decoding process occurs after the encoding 


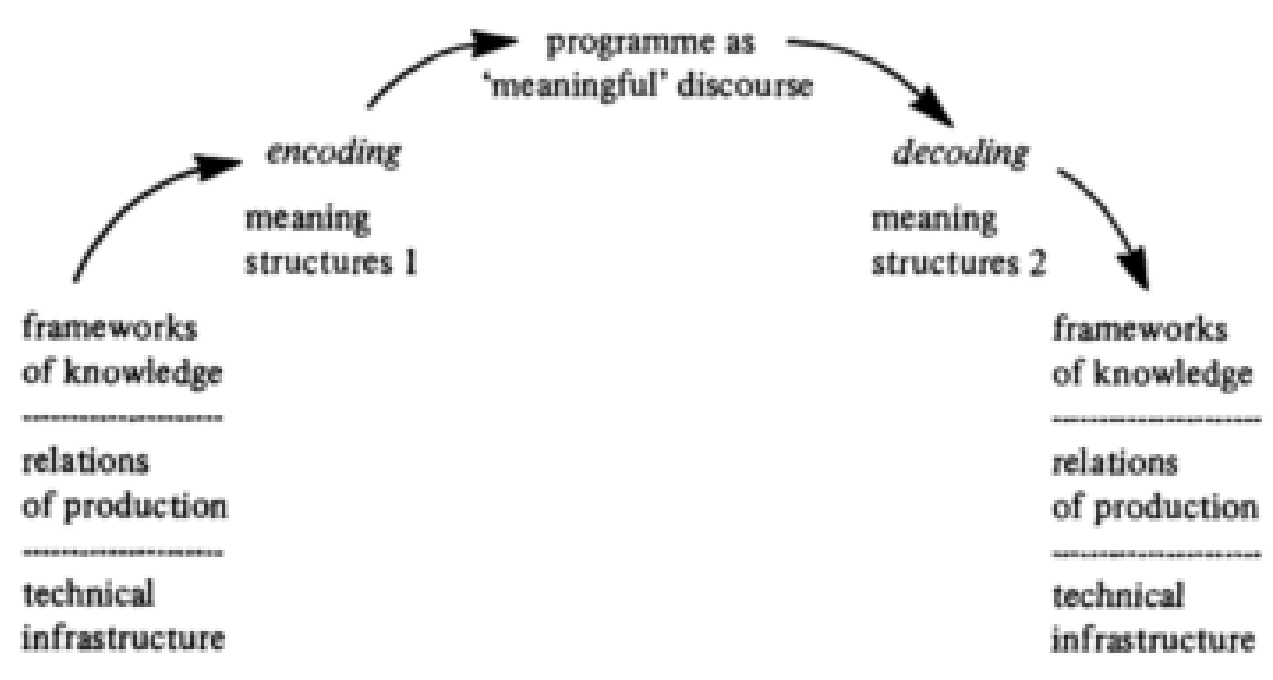

Picture 2. Stuart Hall's encoding/decoding chart (Hall, 1980)

is done. In this process, the decoder retranslates the messages of the encoder by the process of making codes. Hall revealed that meaning structures 1: 'meaningful messages produced' and meaning structures 2: 'meaningful messages received' are not always symmetrical, so the form of decoders' reception varies. The simpler explanation is that the sender's message may not be the same as the message accepted by the receiver.

With encoding/decoding theory, Hall categorizes the acceptance or decoding into three categories: the first is called the dominant-hegemonic position in which the audience fully accepts the messages lying under the dominant ideology without any rejection or disapproval. The audience explains their own lives, behaviour, and social experiences under the influence of this ideology. Those acts are categorized as "operating inside the dominant code." The second is called negotiated code, which explains the audience who mixed their interpretations with their particular social experiences. In this category, the audience may act adaptively and oppositely on the process of interpreting the message. The third is called oppositional code, in which the audience entirely opposes the presented message. The audience may do a different way of reading from what the message has been offered (Hall, 1980). The factors that influence the audience's position in perceiving message can be explained through differences in audience perspectives. The perspective itself refers to contexts, such as cultural settings and personal experiences (Pertiwi et al., 2020).

First, in the dominant-hegemonic category, five informants match to this category. They are Dhimas, Aziz, Isna, Alya, and Dewi. The five informants agree and accept the encoder's message, which is The Luntas, in accordance with the strategy or mission of The Luntas itself. As stated by Mita' The Luntas', one of their strategies that are used to attract young audiences is to use daily language and understandable comedy. This is also agreed by the informants who say that the main interest of The Luntas is the daily local language, which is Boso Suroboyoan and comedy with slapstick jokes and silly wordplay, as seen in the following interview excerpt. 
"Because I like their silly jokes, furthermore (the jokes) are understandable for Suroboyo youth" (Dhimas).

"If I may speak frankly, Luntas is more suitable for the young soul of mine. The language is understandable, the humour and the messages of the story are more familiar [...] personally, I prefer (to watch) Luntas because it is more suitable for young people like me and in terms of language, message, and humour, it is more acceptable..." (Dewi).

Based on these data, it can be seen that the reason for the informants' interest toward The Luntas lies in the language that is used in the performance. In the process of reception, the retranslated message is influenced by the visualization of the audience's social life (Fathurizki \& Malau, 2018). Boso Suroboyoan (dialectic Surabaya style), which is in accordance with the place where this ludruk group comes from, turns out to have a certain value that brings a positive reaction from the audience. Suroboyoan, which is used in Karesidenan Surabaya, is a variation of the standard formal Javanese language. Karesidenan is a territorial division. Prawiranegara (2004) says that Suroboyoan has a different structure of language compared to formal standard Javanese. The less formal Javanese language of Suroboyoan which may be considered rude and uncultured is being used to show intimacy and its speakers' freedom.

Furthermore, Suroboyoan has some witty impressions that can create a friendly and pleasant atmosphere among the speakers. The modern elements in each of The Luntas performances become an attraction point for the audience. It is also supported by the freshness of the story themes, which are interesting for the audience.
"Besides the duration, Luntas also dares to include the elements of popular culture. Modern young people or even adults who keep up with the movement of the era prefer to watch modern performances, and in my opinion, Luntas succeeded in uniting these elements, which are traditional elements and popular cultures" (Aziz).

"If (I am allowed to speak), Luntas is more suited to the young soul of mine [...] (they are) more contemporary, more 'up to date' from various aspects. As young people, we need something fresh (from a performance), and Luntas can present it for the audience [...] the traditional elements are still shown but in a way that easier for young people to understand" (Dewi).

Based on the excerpts, it appears that the five informants agree and fully receive the meaning of the messages that were produced by the encoder, which is The Luntas. The Luntas can reach the audience's attention by presenting a more exciting and straightforward performance withoutleaving any traditional elements. The majority of The Luntas' audience is the young generation who live in the spirit of the times interested in short stage performances. This is considered different from the older generation who are bear to watch full performances. A modern presentation without leaving traditional elements becomes a value-added because The Luntas indirectly presents works that are in accordance with the interests of the audience, young generation with tastes and interests towards new or completely present things.

The next category is the negotiated code. Four informants were put into this category named Rany, Danang, Adnan, and Hamdan. These four informants might capture and understand the strategy of The Luntas, but they also had an exception at some points. 
The first example is the informant Rany. Rany considered that delivering humour makes The Luntas funnier than any perform she has watched. She also said that The Luntas storylines come from the daily struggle of young people, which became the main attraction of the performance. This is the following interview excerpt:

“...Luntas' performance was even funnier than other performances I had watched [...] the formed material (of the storyline) was close to the daily problems that were encountered by young people" (Rany).

However, when she asked whether the appeal was the reason Rany would watch The Luntas's performance in the future, she answered no. The attraction of The Luntas is not Rany's motivation in order to watch the performance, but rather than because Rany likes East Javanese art. She will continue to watch any ludruk performance, no matter what ludruk groups are.

The next informant is Danang. Danang says that the performance of The Luntas is more modern because The Luntas do not invite the gamelan players. However, he prefers the traditional ludruk because the traditional ludruk group uses complete gamelan. Danang's family is an East Java's art enthusiast. Even his uncle, Pak Semar, is a Surabaya cultural enthusiast, book writer, and cultural history artist who is well respected in Surabaya. Danang is used to watching traditional ludruk performances such as Supali CS, one of the famous ludruk groups in East Java. Fiske (1990) argues that the active audience carries his own values and experiences in the process of reception. Therefore, Danang considers that one of the most important ludruk's elements comes from its gamelan instrument played on traditional ludruk performance.

\begin{abstract}
"Yep, if (it considered on) the stage setting, it was rather different, it is more modern. Usually, ludruk is identical with live gamelan instrumental, (but) Luntas' performance was only using (recorded) music; it felt less (complete) [...] Yes, if I need to choose, (I choose) the traditional one [...] what I need to say, the traditional one is better, ludruk's characteristic is the gamelan instrument itself" (Danang).
\end{abstract}

Although Danang prefers traditional ludruk, Danang is still interested in The Luntas performance in the future. The reason for his answer is because he likes any ludruk performance. Danang adds that modern ludruk like The Luntas is not a problem because he thinks that modernity always follows all human aspects of life, including arts. Although his tastes still traditional ludruk.

The next informant is Adnan. Adnan is considered as the person who watches the most of ludruk performances, both traditional and modern. According to Adnan's opinion, The Luntas, as a modern ludruk group, has an attraction point because of their ability to innovate the traditional ludruk standards. It is explained in the following interview excerpt.

"The innovation (of The Luntas) has countered the standard (of traditional ludruk). Other than that, they involve young men and women in the process of their performance. Then about the clothes in (one of the scene of) Bedayan, they changed the usual clothes into, ugh I forgot what it was called (its name) cheerslek clothes. Then, the performance was shorter [...] It could be (an attraction point), (so people will) be curious (to that performance)" (Adnan).

Nevertheless, Adnan prefers traditional ludruk performance. The traditional ludruk has nostalgic nuance from the old days for Adnan. However, Adnan still wants to 
watch the next performance of The Luntas if he gets the opportunity. He loves watching any ludruk performance after all.

The last informant is Hamdan. Hamdan admits that one of the attractions of The Luntas is exciting storylines, so the story is not easy to be guessed by the audience. Nevertheless, Hamdan prefers the traditional ludruk because he considered that modern ludruk has no original gamelan instrument during the performance. In Hamdan's opinion, the complete ludruk performance should include a real gamelan instrument. Furthermore, he says he does not feel any classical nuance during the performance. This is the following interview excerpt.

"Maybe it is less classical [...] Just to support the atmosphere, I prefer the classic one [...] Yes (the performance is reducing traditional elements), the power of ludruk is in the instrument..." (Hamdan).

Based on the informants' opinions, it can be seen that although they are interested in The Luntas' styles and ways, most of the informants on this category feel the lack of presentation of traditional nuance in the performance. The absence of a gamelan instrument is considered to reduce the traditional value in a ludruk performance rich in classical Javanese culture.

The last category is oppositional. From the overall explanation of the informant, no informant entirely opposes what is presented by The Luntas. This can be seen from the audience's immense interest in watching The Luntas stage and even considering it as a positive effort to preserve ludruk culture. None of the informants refuse, feel clueless, or not accept the messages generated by the encoder. All messages are received and understood in the form of pleasant entertainment.

\section{Conclusion}

Based on the current research, it can be seen that The Luntas tries to preserve the ludruk culture by modernizing ludruk so that it can be accepted by urban communities, especially the younger generation of Surabaya. In addition, it can also be understood to what extent the pattern of The Luntas message acceptance is in its performance to the audience based on the results of the encoding and decoding analysis. Based on the results of interviews conducted with nine informants, five informants are categorized into the dominant-hegemonic. Meanwhile, the remaining four people are included in the negotiated code, and none of the informants is in the oppositional category.

In the dominant-hegemonic category, it can be understood that the use of Boso Suroboyoan by The Luntas turns out to be the main interest of the performance. The Boso Suroboyoan, which is considered informal and witty, has a valuable aspect for The Luntas' performance. An easily understood practical joke, simple costume, and properties, a smaller number of stage players, and no gamelan players make The Luntas performance be considered to be attractive to the young audience.

However, the innovation of traditional ludruk standards by The Luntas does not always get a positive reaction from the audiences. Some of the informants feel less sense of tradition in The Luntas' performance. The Luntas is still not able to satisfy the desires of ludruk traditional culture enthusiasts. This can be seen from some informants' disappointment towards using electronic music instruments rather than real gamelan instruments. Without gamelan instruments, the performance turns out to diminish the essence of the traditional 
ludruk performance. On the other hand, there is no audience against The Luntas' performance at all. They prefer to think that The Luntas' performance is part of fun entertainment, especially it has a positive value in preserving Indonesian culture.

Finally, it can be said that although The Luntas has not been able to present a perfect performance, in the end, it has succeeded in bringing the main message, namely to become a ludruk group that can enter modern society, which cannot be entered by conventional ludruk performances. Complementing previous research, The Luntas can change younger audiences' minds about ludruk performances, generally known as boring old shows. On the other hand, as the next generation, the audience of The Luntas is still enthusiastic about enjoying various performances of The Luntas. The content of The Luntas performance, which is fluid and adaptable to the time development, ultimately becomes an innovative cultural product capable of combining rigidity, distance, and time, as an effort to preserve Indonesian traditional culture so that it continues to exist.

\section{Declaration of Ownership}

This article is our original work.

\section{Conflict of Interest}

There is no conflict of interest to declare in this article.

\section{Ethical Clearance}

This study was approved by the institution.

\section{References}

Azali, K. (2016). Ludruk: Masihkah ritus modernisasi? Lakon: Jurnal Kajian Sastra dan Budaya, 1(1), 48-60. https://doi. org/10.20473/lakon.v1i1.1916

Barker, C. (2014). Kamus kajian budaya. Kanisius.

Bintari, P. N., \& Darmawan, C. (2016). Peran pemuda sebagai penerus tradisi sambatan dalam rangka pembentukan karakter gotong royong. Jurnal Pendidikan Ilmu Sosial, 25(1), 57-76. https://doi. org/10.17509/jpis.v25i1.3670

Bisri, H. (2000). Pengelolan organisasi seni pertunjukan. Harmonia: Journal of Arts Research and Education, 1(1). https://doi. org/10.15294/harmonia.v1i1.838

Dwita, D., \& Sommaliagustina, D. (2018). Interpretasi feminisme: Analisis resepsi khalayak Pekanbaru tentang film "Kartini." Jurnal Perspektif Komunikasi, 2(2). https://jurnal.umj.ac.id/index.php/ perspektif/article/view/3954/2928

Faiqah, F., Nadjib, M., \& Amir, A. S. (2016). Youtube sebagai sarana komunikasi bagi komunitas makassarvidgram. Jurnal Komunikasi Kareba, 5(2), 259-272. https:// doi.org/10.1080/14639947.2015.1006801

Fathurizki, A., \& Malau, R. M. U. (2018). Pornografi dalam film: Analisis resepsi film "Men, Women \& Children." ProTVF, 2(1), 19-35. https://doi.org/10.24198/ptvf. v2i1.11347

Fiske, J. (1990). Cultural and communication studies: Sebuah pengantar paling komprehensif. Jalasutra.

Ghony, M. D., \& Almanshur, F. (2014). Metode penelitian kualitatif. Ar-Ruzz Media.

Hall, S. (1980). Encoding/decoding. In S. Hall, D. Hobson, A. Lowe, \& P. Willis (Eds.), Culture, media, language (pp. 128138). Hutchinson University Library.

Hendriani, D. (2012). Hasan Basori dan kesenian ludruk marjinal di Sidoarjo. 
Jurnal Lembaran Sejarah, 9(2), 57-72. https://doi.org/10.22146/lembaransejarah.23774

Ida, R. (2011). Metode penelitian kajian media dan budaya. Airlangga University Press.

Iskandar. (2009). Metodologi penelitian kualitatif. GP Press.

Ismail, R. (2017). Musik rock alternatif dalam kalangan remaja: Isu sub-budaya remaja dan pembangunan insan dalam era globalisasi. Jurnal Antropologi: Isu-Isu Sosial Budaya, 19(1), 11-25. https://doi. org/10.25077/jantro.v19i1.66

Nawawi, H., \& Martini. (1996). Penelitian terapan. Gajah Mada University Press.

Njo, S., Hartanto, D. D., \& Sylvia, M. (2017). Perancangan promosi ludrukan nomnoman Tjap Arek Soeroboio. Jurnal DKV Adiwarna, 2(11). http://publication. petra.ac.id/index.php/dkv/article/ view/6321/5745

Peacock, J. L. (2005). Ritus modernisasi aspek sosial $\mathcal{E}$ simbolik teater rakyat Indonesia. Desantara.

Pertiwi, M., Ri'aeni, I., \& Yusron, A. (2020). Analisis resepsi interpretasi penonton terhadap konflik keluarga dalam film "Dua Garis Biru." Jurnal Audiens, 1(1), 1-8. https://doi.org/10.18196/ja.1101

Prabowo, D. (2013). Ini kategori baru disebut pemuda berdasar umur yang diusulkan oleh Menpora. http://m.tribunnews.com/ amp/nasional/2013/08/20/ini-kategoribarupemuda-berdasar-umur-yangdiusulkan-menpora

Prasisko, Y. G. (2018). Ludruk Jember: Ritual masyarakat perantauan. Parafrase: Jurnal Kajian Kebahasaan \& Kesastraan, 18(1), 6978. https://doi.org/10.30996/parafrase. v18i01.1384

Prawiranegara, Y. (2004, January 25). Bahasa egaliter pojok kampung. Jawa Pos.

Putra, I. B. (2018). Kesenian ludruk di Surabaya (studi deskriptif mengenai upaya paguyuban
"Luntas" dalam menghidupkan kembali eksistensi kesenian tradisional ludruk sebagai atraksi wisata di Surabaya) [Universitas Airlangga]. http://repository.unair.ac.id/ id/eprint/71722

Riswari, A. A. (2019). Komunitas Surabaya Wotagei: Sebuah kajian budaya populer. Jurnal Antropologi: Isu-Isu Sosial Budaya, 21(1), 121-131. https://doi.org/10.25077/ jantro.v21.n1.p121-131.2019

Setyawati, R. D. (2019). Pelestarian kesenian ludruk : Studi kasus grup Marsudi Laras di Surabaya tahun 2003-2017. Avatara, 7(3), 1-8. https://jurnalmahasiswa. unesa.ac.id/index.php/avatara/article/ view/29398/26926

Smolik, J. (2013). Youth subcultures and social pedagogy. KulturaSpołeczeństwo: Edukacja, 2(4), 65-81. http://yadda.icm.edu.pl/yadda/element/ bwmeta1.element.ojs-doi-10_14746_ kse_2013_4_2_05/c/10965-10550.pdf

Storey, J. (2006). Cultural theory and popular culture:Anintroduction. In Cultural theory and popular culture. Pearson Prentice Hall. https://doi.org/10.4324/9781315832968

Sugihartati, R. (2017). Budaya populer dan subkultur anak muda. Airlangga University Press.

Sukmadinata, N. S. (2011). Metode penelitian pendidikan. Rosda.

Suryadi, M. (2018). Keanekaragaman tipe tuturan krama pada masyarakat Jawa pesisir sebagai bentuk kedinamikaan dan keterbukaan bahasa Jawa kekinian. Humanika, 25(1), 1-11. https://doi. org/10.14710/humanika.v25i1.13337

Trisnani. (2017). Pemanfaatan Whatsapp sebagai media komunikasi dan kepuasan dalam penyampaian pesan di kalangan tokoh masyarakat. Jurnal Komunika: Jurnal Komunikasi, Media dan Informatika, 6(3), 1-12. https://doi.org/10.31504/ komunika.v6i3.1227 